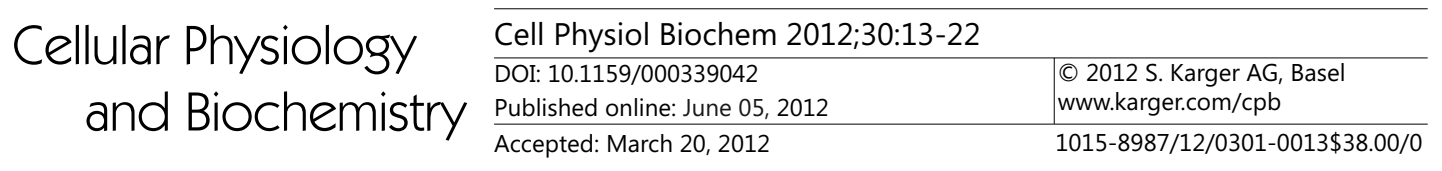

\title{
Suppression of Inflammatory Cytokine Secretion by an NF- $\kappa$ B Inhibitor DHMEQ in Nasal Polyps Fibroblasts
}

\author{
Fabiana C.P. Valera ${ }^{1}$ Kazuo Umezawa ${ }^{2}$ María S. Brassesco ${ }^{3}$ Angel M. Castro-Gamero ${ }^{4}$ \\ Rosane G.P. Queiroz ${ }^{3}$ Carlos A. Scrideli ${ }^{3}$ Luiz G. Tone ${ }^{3}$ Wilma T. Anselmo-Lima ${ }^{1}$
}

\begin{abstract}
${ }^{1}$ Division of Otorhinolaryngology, School of Medicine of Ribeirão Preto - University of São Paulo, São Paulo, ${ }^{2}$ Department of Applied Chemistry Yokohama, Faculty of Science and Technology - Keio University, Keio, ${ }^{3}$ Department of Pediatrics, School of Medicine of Ribeirão Preto - University of São Paulo, São Paulo, ${ }^{4}$ Department of Genetics, School of Medicine of Ribeirão Preto - University of São Paulo, São Paulo
\end{abstract}

\section{Key Words}

DHMEQ $•$ Fluticasone propionate $\cdot$ Glucocorticoid $\bullet$ Nasal polyps $\bullet$ NF-kappaB $\bullet$ Rhinosinusitis

- Dehydroxymethylepoxyquinomicin •In vitro culture $\cdot$ Polyps fibroblasts $・$ Topical steroid

\begin{abstract}
Background: NF- $\mathrm{KB}$ is an essential transcription factor strongly associated to inflammatory response in chronic rhinosinusitis with nasal polyps (CRSWNP). DHMEQ is a NF-kB inhibitor that has been previously described with a greatpotential indecreasing inflammation in diseases other than CRSWNP. The aim of study isto evaluate the ability of DHMEQ to reducethe inflammatory recruiters on CRSWNP and to compare its anti-inflammatory profile as a singleagent or in association with fluticasone propionate (FP). Methods: nasal polyp fibroblasts were cultured in TNF- $\alpha$ enriched media. Cells were submitted to three different concentrations $(1,10$ and $100 \mathrm{nM})$ of either FP, DHMEQ or both. Inflammatory response was accessed by VCAM-1, ICAM-1 and RANTES expression (by RTQ-PCR) and protein levels by ELISA. Nuclear translocation of NF-KB was also evaluated. Results: both FP and DHMEQ inhibited inflammatory recruiters' production and NF- $\mathrm{KB}$ nuclear translocation. Interestingly, the antiinflammatory effect from the association steroids plus DHMEQ was more intense than of each drug in separate. Conclusion: DHMEQ seems efficient in modulating the inflammatory process in CRSwNP. The synergic anti-inflammatory effect of DHMEQ and steroids may be a promising strategy to be explored, particularly in the setting of steroid-resistant NP.
\end{abstract}




\begin{tabular}{|c|c|c|}
\hline Coll & Cell Physiol Biochem 2012;30:13-22 & \\
\hline and Biochemistry & $\begin{array}{l}\text { DOI: } 10.1159 / 000339042 \\
\text { Published online: June } 05,2012\end{array}$ & $\begin{array}{l}\text { O } 2012 \text { S. Karger AG, Basel } \\
\text { www.karger.com/cpb }\end{array}$ \\
\hline
\end{tabular}

\section{Introduction}

Chronic rhinosinusitis with nasal polyps (CRSwNP) is an upper airway disease characterized by a remarkable recruitment of inflammatory cellson nasal mucosa [1-3], particularly eosinophils, in a mixed Th1/Th2 profile of inflammation, with a Th2 polarization [4-5]. In this process, fibroblasts, epithelial and endothelial cells are important producers of pro-inflammatory molecules (such as the adhesion molecules VCAM-1 and ICAM-1) and chemokines RANTES, eotaxin and eotaxin-2 [6-8]. Migrated inflammatory cells (such as lymphocytes and eosinophils) produce other several cytokines and chemokines, which will increase cell recruitment and survival $[6,9,10]$, and thus reverberate inflammation [7].

Because of its broad effect on pro-inflammatory molecules [7], topical glucocorticoid (GC) is the medication of choice to initially treat CRSwNP $[11,12]$. The GC-GR (glucocorticoid receptor) dimmer acts as a negative transcription factor (TF) through the inhibition of other TFs, particularly AP-1 and NF- $\mathrm{\kappa B}[7,13,14]$.

Recently, our group described higher expression of NF- $\mathrm{KB}$ in CRSwNP compared to normal nasal mucosa [15]. Moreover, higher NF- $\kappa B$ expression was correlated to impaired medical treatment outcome with topical glucocorticoids $[16,17]$. As a result, we suggested that NF- $\kappa B$ expression could be an important inducer of inflammation and GC resistance for CRSwNP.

The concept of a potent anti-inflammatory drug with reduced side effects is quite an interesting concept to be chased in CRSwNP. In this regard, dehydroxymethylepoxyquinomicin (DHMEQ) is a NF- $\mathrm{KB}$ inhibitor derived from the antibiotic epoxyquinomicin C $[18,19]$. This drug has shown to directly inhibit the nuclear translocation and transcription of NF- $\kappa B$ without apparent toxic side effects $[19,20]$. Since DHMEQ has previously shown to display anti-inflammatory and anti-fibrotic effects [19], and NF- $\kappa B$ expression was increased in CRSwNP, we considered rational to evaluate the effects of DHMEQ on CRSwNP, either alone or in association to GC.

The objective of the present study is to assess and compare the effect of DHMEQ tofluticasone propionate (FP) in reducing the expression of the pro-inflammatory molecules VCAM-1, ICAM-1 and RANTES in NP (nasal polyps) fibroblasts, either isolated or in association to this steroid.

\section{Materials and Methods}

Patients with bilateral inflammatory CRSwNP (confirmed by endoscopy and CT scans) that failed to a three-month medical treatment (including topical and systemic glucocorticoids and, if needed, short-course of antibiotics) were eligible for this study. Patients with ciliary dyskinesia, cystic fibrosis, AERD (aspirin exacerbated respiratory disease), smoking and severe asthma were excluded.

After giving informed consent, 6 consecutive patients performed a one-month-withdraw of any medication, and NP specimens were collected during endoscopic nasal surgery. The present study was approved by Ethics local IRB (process number 4374/2007).

\section{Cell culture}

A polyp biopsy was aseptically collected, minced into $0.5 \mathrm{~mm}$ fragments and disaggregated with collagenase type-IV for 2 hours. The fibroblasts were centrifuged, displayed in flasks supplemented with HAM-F10 (+1\% penicillin, $1 \%$ streptomycin, and $20 \%$ fetal calf serum) and cultured at $37^{\circ} \mathrm{C}$ in a $5 \% \mathrm{CO}_{2}$ atmosphere.

After reaching $90 \%$ of confluence (one million cells/flask), cells were trypsinized and fibroblast lineage was confirmed by light microscope and flow cytometry [21]. Only cultures containing at least $95 \%$ of fibroblasts were studied.

Initially, drug toxicity was assessed, with concentrations from 1 to up $40000 \mathrm{nM}$ of DHMEQ, PF or both for up to 72 hours. Cell viability was assessed through Trypan-Blue and apoptosis assays, and clonogenic assay was also performed. 


\section{Cellular Physiology and Biochemistry \\ Cell Physiol Biochem 2012;30:13-22 \\ \begin{tabular}{l|l}
\hline DOI: $10.1159 / 000339042$ & C 2012 S. Karger AG, Basel
\end{tabular} \\ Published online: June 05, 2012 \\ www.karger.com/cpb}

For apoptosis assessment, a total of $3 \times 10^{5}$ cells were seeded in $25 \mathrm{~cm}^{2}$ tissue culture flasks containing $5 \mathrm{~mL}$ of culture medium. After $24 \mathrm{~h}$, the medium was replaced, propolis and DMSO were added, and then the cells were cultured for additional $48 \mathrm{~h}$. Apoptotic cells were recognized by nuclear condensation and fragmentation, according to Lee and Shacter [22]. Treated cells were centrifuged and incubated for 5 min at $37^{\circ} \mathrm{C}$ with bisbenzimide (Hoechst 33342), propidium iodide and fluorescein diacetate (Sigma Chemical Co., St. Louis, USA). Then, samples were mounted on slides, cover slipped and analyzed by fluorescence microscopy with a triple filter. Cells were scored and categorized according to differential staining: (1) normal: blue nucleus and green cytoplasm, (2) apoptotic: fragmented blue nucleus and green cytoplasm, and (3) necrotic: spherical red nucleus. 500 nuclei were analyzed per treatment.

\section{Cell treatment design}

After knowing the toxicity level of each drug, fibroblasts were then treated as follows:

- negative (free of drugs) and positive control (TNF- $\alpha$ : $25 \mathrm{ng} / \mathrm{mL}$ )

- FP treatment: positive control added to: FP1 (1nM/0.45mg/mL), FP10 (10nM/4.5mg/mL) and FP100 $(100 \mathrm{nM} / 45 \mathrm{mg} / \mathrm{mL})$.

- DHMEQ treatment: positive control added to:DHMEQ1 (1nM/0.25mg/mL), DHMEQ10 (10nM/2.5mg/mL) and DHMEQ100 (100nM/25mg/mL).

- DHMEQ+FP: positive control added to: DHMEQ+FP1 (1nM DHMEQ and 1nM FP),

- DHMEQ+FP10 (10nM DHMEQ and 10nM FP) and DHMEQ+FP100 (100nM DHMEQ and 100nM FP).

To evaluate the anti-inflammatory effect, experiments were incubated for 24 hours only. Then, cells were harvested, trypsinized and stored in Trizol ${ }^{\circledR}$ (for RNA studies) and dimethyl sulfoxide(DMSO - for nuclear extraction) at $-80^{\circ} \mathrm{C}$. Culture media was stored at $-20^{\circ} \mathrm{C}$ for ELISA study.

Elisa

Protein concentration of RANTES, sICAM-1 and sVCAM-1 was quantified in the culture medium by ELISA according to the manufacturer instructions (Biosource, CA, USA), and normalized to total protein measured by Bradford's method.

\section{PCR}

RNAs were extracted with Trizol, and cDNAs were prepared with the High Capacity cDNA archive kit. The following TaqMan ${ }^{\circledR}$ (Applied Biosystems) primers and probes were used: Hs00164932_m1(ICAM-1), Hs00174575_m1(RANTES) and Hs00365486_m1(VCAM-1), in addition to the housekeeping Hs00266705_ g1(GAPDH). The final primer concentration was $900 \mathrm{nM}$ and the final TaqMan probe concentration was 300 nM.

Nine $\mu \mathrm{L}$ of the sample (diluted 1:10) was added to $10 \mu \mathrm{L}$ of Universal PCR Master Mix (Applied Biosystems) and $1 \mu \mathrm{L}$ of the probe. The plates were centrifuged for 10 seconds at $13000 \mathrm{rpm}$. All steps were carried out with the samples immersed in ice and little exposure to light. The final PCR conditions were: preheating to $50^{\circ} \mathrm{C}$ for 2 minutes, denaturation at $95^{\circ} \mathrm{C}$ for 10 minutes and 40 cycles of amplification and quantitation $\left(15\right.$ seconds a $95^{\circ} \mathrm{C}$ and 60 seconds a $60^{\circ} \mathrm{C}$ ) in 7500 Real-Time PCR System ${ }^{\circ}$ (PE Applied Biosystems). Each sample was tested in duplicate, and negative controls and calibrators were amplified in parallel to determine the efficiency of each experiment. Relative gene expression was calculated using the $2^{-\Delta \Delta C T}$ method.

\section{Nuclear extraction}

To evaluate nuclear translocation of NF- $\mathrm{\kappa B}$, cell membranes were ruptured and nuclei were isolated. Cells were centrifuged at 13200 rpm for 5 minutes; the pellet was washed twice in ice-cold PBS and incubated for 15 minutes with ice-cold buffer-A (10mmol/L HEPES,pH7.9;10mmol/L KCl;0.1 mmol/L EDTA;0.1mmol/ L EGTA;1mmol/L DTT; $1 \mathrm{mg} / \mathrm{L}$ aprotinin; $1 \mathrm{mg} / \mathrm{L}$ leupeptin; and1 $\mathrm{mg} / \mathrm{L}$ pepstatinA). After cell membrane lysis, $5 \mu \mathrm{L} 0.1 \%$ NP-40 was added; solution was vigorously vortexed for 1 minute, and centrifuged at $20,800 \mathrm{~g}$ for 5 minutes at $4^{\circ} \mathrm{C}$. The supernatant (cytoplasmic fraction) was discarded and the nuclear pellets were suspended in $50 \mu \mathrm{L}$ of ice-cold buffer-B $(20 \mathrm{mmol} / \mathrm{L}$ HEPES, pH 7.9;420mmol/L NaCl;0.1mmol/L EDTA;0.1mmol/L EGTA; 1mmol/L PMSF;1 mmol/L DTT;1mg/L aprotinin;1mg/L leupeptin; and 1mg/L pepstatin), at $4^{\circ} \mathrm{C}$ for 30 minutes with periodic vortexing, centrifuged at $20800 \mathrm{~g}$ for 5 minutes at $4{ }^{\circ} \mathrm{C}$, and the supernatant (nuclear fraction) was stored at $-80^{\circ} \mathrm{C}$. The protein quantification of NF- $\mathrm{KB}$ was by ELISA(Total NF-kBp65, Biosource, Camarillo CA, USA). 


\section{Cellular Physiology \\ Cell Physiol Biochem 2012;30:13-22 \\ and Biochemistry \\ \begin{tabular}{l|l}
\hline DOI: $10.1159 / 000339042$ & C 2012 S. Karger AG, Basel
\end{tabular} \\ Published online: June 05, 2012 \\ www.karger.com/cpb}

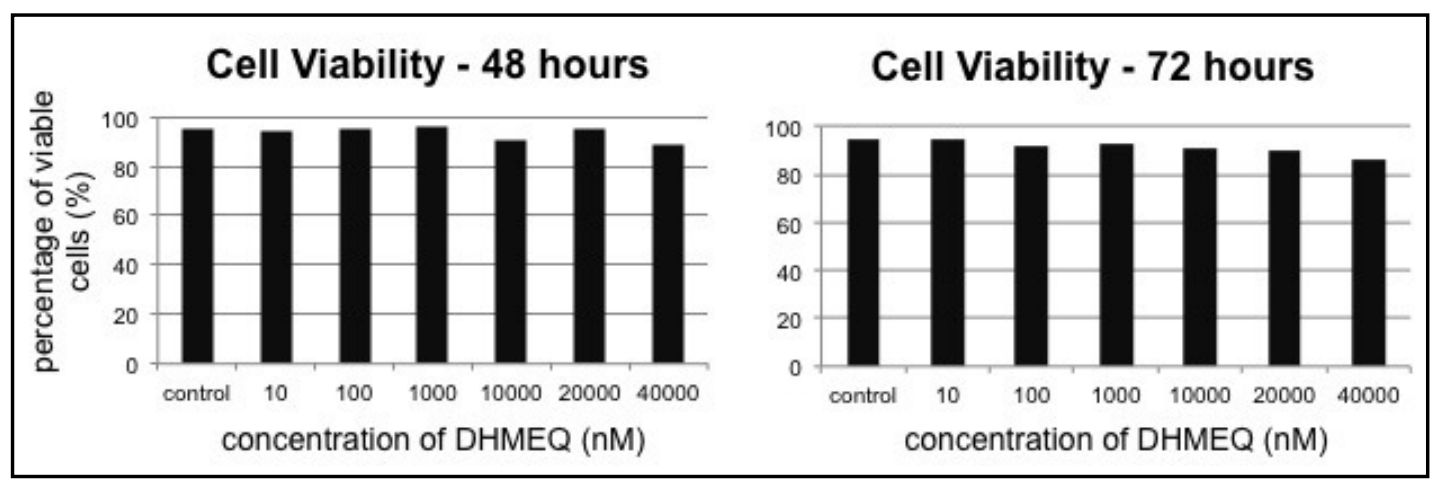

Fig. 1. Cell viability of nasal polyps fibroblasts exposed to DHMEQ concentrations from 1 up to $40000 \mathrm{nM}$ for 48 (1a) and 72 hours (1b).

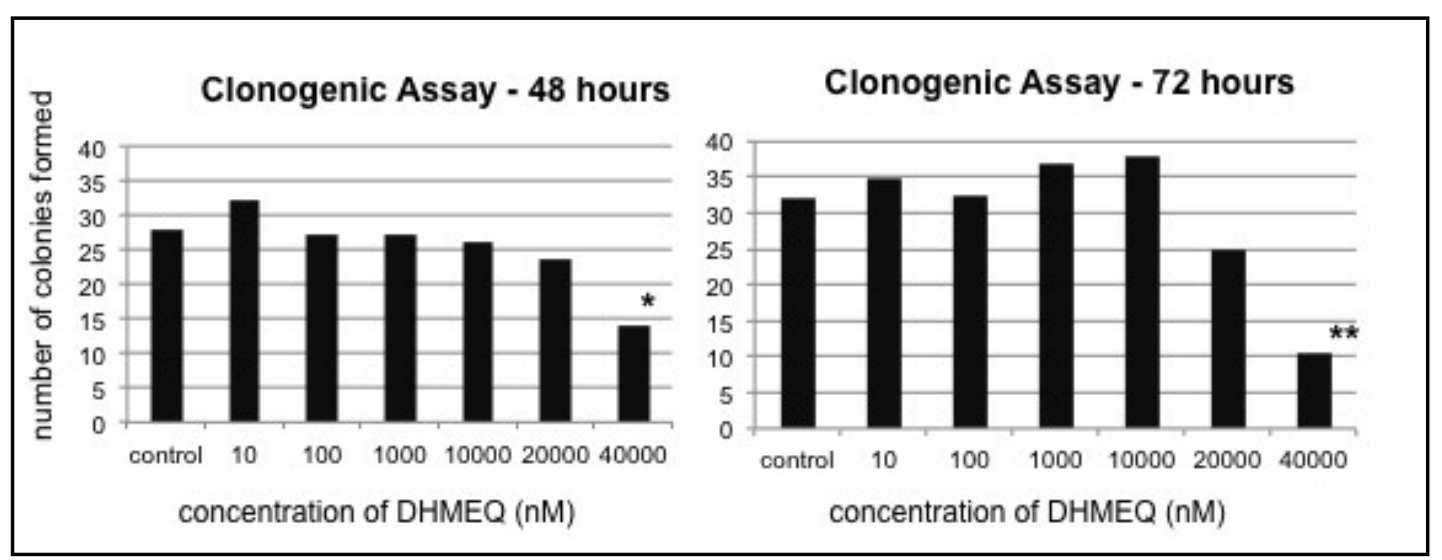

Fig. 2. Clonogenic Assay of nasal polyps fibroblasts exposed to DHMEQ concentrations from 1 up to 40000 nM for $48(2 \mathrm{a})$ and 72 hours (2b). ${ }^{*} \mathrm{P}<0.05$; ${ }^{* *}: \mathrm{P}<0.01$.

Statistical analysis

All reactions were analyzed and compared by the Student t-test for paired samples, with the level of significance set at $\mathrm{P}<0.05$. Results are presented in means and standard deviations.

\section{Results}

\section{Fibroblast cultures}

Five NP fibroblasts cultures displayed more than 98\% positivity for CD90 and less than $1 \%$ positive for CD34, confirming the specificity of fibroblasts composition. One sample presented only $92 \%$ of cells positive to CD90 and was excluded from the study.

Cell viability, apoptosis and clonogenic assays were tested in concentration from 1 to $40000 \mathrm{nM}$ of DHMEQ during 24, 48 and 72 hours. Cell viability and apoptosis assays demonstrated that more than $90 \%$ of the fibroblasts were viable and non-apoptotic up to $10000 \mathrm{nM}$ of DHMEQ; at the concentrations of $20000 \mathrm{nM}$ and $40000 \mathrm{nM}$, cell viability remained between 85 and 90\%, being significantly similar to control (Fig. 1). Clonogenic assay significantly decreased at the concentration of $40000 \mathrm{nM}$ in both analyzed periods (Fig. 2).

NP viability significantly decreased with $1000 \mathrm{nM}$ of FP (data not shown). As we chose for a comparative study between drugs, the studied concentrations were set at 1,10 and $100 \mathrm{nM}$ of each drug. 


\section{Cellular Physiology and Biochemistry}

Cell Physiol Biochem 2012;30:13-22

\begin{tabular}{l|l}
\hline DOI: $10.1159 / 000339042$ & $\begin{array}{l}\text { C) } 2012 \text { S. Karger AG, Basel } \\
\text { www.karger.com/cpb }\end{array}$
\end{tabular}

$\begin{array}{ll}\text { Published online: June 05, } 2012 & \text { www.karger.com/cpb } \\ \text { Valera/Umezawa/Brassesco et al.: DHMEQ Study in Nasal Polyps Fibroblasts }\end{array}$

Table 1. Protein concentrations of sICAM-1, s-VCAM-1 and RANTES, after TNF- $\alpha$ stimulation, either alone or associated to different drugs and concentrations.Mean values and standard deviations, in folds compared to negative controls. $P$ values when data were compared to positive controls. *: $\mathrm{P}<0.05$

\begin{tabular}{lllll}
\hline Stimulation & & SICAM-1 & s-VCAM-1 & RANTES \\
\hline TNF- $\alpha$ & & $3.17 \pm 0.77$ & $2.17 \pm 0.66$ & $4.78 \pm 1.57$ \\
TNF- $\alpha+$ FP & $1 \mathrm{nM}$ & $2.57 \pm 1.14$ & $1.35 \pm 0.61$ & $2.78 \pm 2.26^{*}$ \\
& $10 \mathrm{nM}$ & $2.17 \pm 0.44$ & $1.29 \pm 0.72^{*}$ & $2.38 \pm 1.23^{*}$ \\
& $100 \mathrm{nM}$ & $1.65 \pm 0.44^{*}$ & $1.20 \pm 0.50^{*}$ & $1.64 \pm 0.54^{*}$ \\
TNF- $\alpha+$ & $1 \mathrm{nM}$ & $2.32 \pm 0.96$ & $1.36 \pm 0.40^{*}$ & $1.62 \pm 0.44$ \\
DHMEQ & $10 \mathrm{nM}$ & $1.78 \pm 0.86$ & $1.12 \pm 0.29^{*}$ & $1.36 \pm 0.50^{*}$ \\
& $100 \mathrm{nM}$ & $1.63 \pm 0.47^{*}$ & $1.06 \pm 0.30^{*}$ & $1.35 \pm 0.44^{*}$ \\
TNF- $\alpha+\mathrm{FP}+$ & $1 \mathrm{nM}$ & $1.29 \pm 0.42$ & $1.29 \pm 0.42$ & $1.28 \pm 0.56^{*}$ \\
DHMEQ & $10 \mathrm{nM}$ & $0.92 \pm 0.34^{*}$ & $1.09 \pm 0.32^{*}$ & $1.05 \pm 0.21^{*}$ \\
& $100 \mathrm{nM}$ & $0.84 \pm 0.32^{*}$ & $0.92 \pm 0.34^{*}$ & $1.02 \pm 0.29^{*}$ \\
\hline
\end{tabular}

Fig. 3. Relative protein concentration of RANTES, ICAM1 and VCAM- 1 in cultures exposed to TNF- $\alpha$ (positive control), FP (1, 10 and 100nM), DHMEQ (1, 10 and $100 \mathrm{nM})$ and FP+DHMEQ (1, 10 and $100 \mathrm{nM}$ of each drug). Comparison to the negative control (considered to be 1.0).
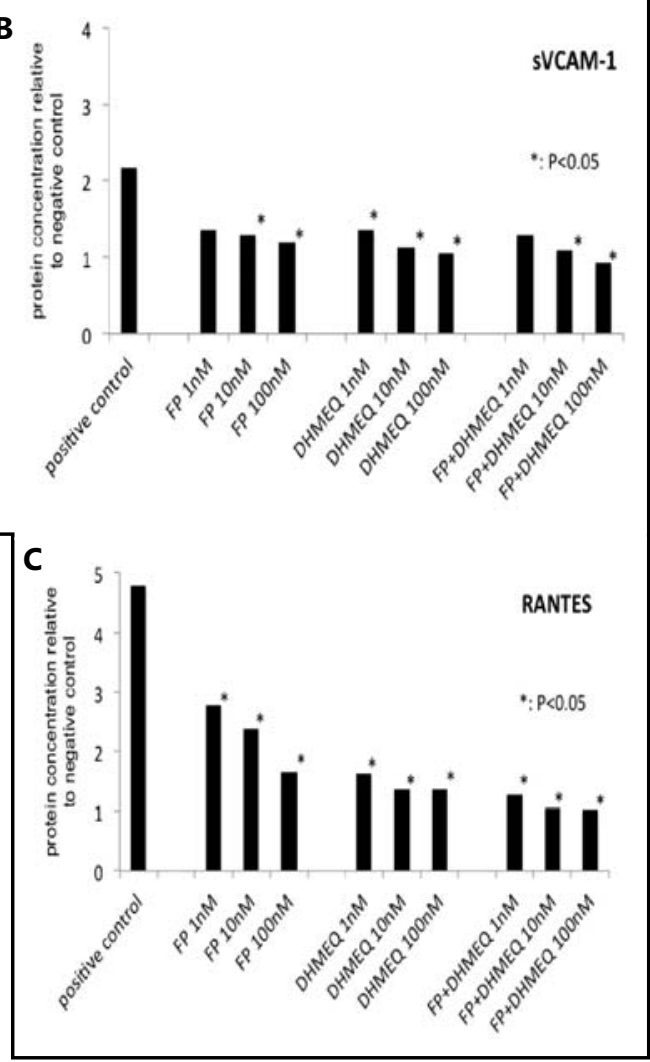

Inflammatory recruiters - protein level (Table 1 and Figs 3a to 3c)

TNF- $\alpha$ at $25 \mathrm{ng} / \mathrm{mL}$ significantly increased protein concentrations of sICAM-1 $(\mathrm{P}=0.0075)$, sVCAM-1 $(\mathrm{P}=0.0173)$ and RANTES $(\mathrm{P}=0.0327)$ when compared to negative control.

FP decreased the studied proteins in a dose-dependent pattern, which was significantly different from positive control at all FP concentrations for RANTES (FP $1 \mathrm{nM}$ vs. TNF- $\alpha$ : $\mathrm{P}=0.0327$ ), at $10 \mathrm{nM}$ and $100 \mathrm{nM}$ for sVCAM-1 (FP $10 \mathrm{nM}$ vs. TNF- $\alpha: \mathrm{P}=0.0402$ ) and at $100 \mathrm{nM}$ of FP for sICAM-1 (FP 100nM vs. TNF- $\alpha$ : $P=0.0476$ ).

DHMEQ also decreased the inflammatory recruiters in a dose-dependent pattern, which was significantly different from positive control at all DHMEQ concentrations for sVCAM-1 (DHMEQ $1 \mathrm{nM}$ vs. TNF- $\alpha$ : $P=0.0146$ ), at $10 \mathrm{nM}$ and $100 \mathrm{nM}$ DHMEQ treatments for RANTES (DHMEQ 10nM vs. TNF- $\alpha$ : $P=0.0371$ ) and at $100 \mathrm{nM}$ of DHMEQ for SICAM-1 (DHMEQ 100nM vs. TNF- $\alpha$ : $P=0.0472$ ). This response was statistically similar to FP.

The association of both drugs (FP and DHMEQ) led to a synergic reduction in inflammatory recruiters, which was significantly different from positive control at all 


\begin{tabular}{|c|c|c|c|c|c|}
\hline \multirow{4}{*}{$\begin{array}{c}\text { Cellular Physiology } \\
\text { and Biochemistry }\end{array}$} & \multirow{2}{*}{\multicolumn{5}{|c|}{ Cell Physiol Biochem 2012;30:13-22 }} \\
\hline & & & & & \\
\hline & \multicolumn{3}{|c|}{$\begin{array}{l}\text { DOI: 10.1159/000339042 } \\
\text { Published online: June 05, } 2012\end{array}$} & \multicolumn{2}{|c|}{$\begin{array}{l}\text { O } 2012 \text { S. Karger AG, Basel } \\
\text { www.karger.com/cpb }\end{array}$} \\
\hline & \multicolumn{5}{|c|}{ Valera/Umezawa/Brassesco et al.: DHMEQ Study in Nasal Polyps Fibroblasts } \\
\hline \multicolumn{3}{|l|}{ Stimulation } & ICAM-1 & VCAM-1 & RANTES \\
\hline \multirow{4}{*}{\multicolumn{2}{|c|}{$\begin{array}{l}\text { TNF- } \alpha \\
\text { TNF- } \alpha+\text { FP }\end{array}$}} & & $29.09 \pm 5.60$ & $10.22 \pm 3.72$ & $31.62 \pm 21.02$ \\
\hline & & $1 \mathrm{nM}$ & $10.94 \pm 10.53^{*}$ & $1.92 \pm 3.52 *$ & $11.35 \pm 2.96$ \\
\hline & & $10 \mathrm{nM}$ & $11.11 \pm 13.00^{*}$ & $2.19 \pm 1.24 *$ & $9.25 \pm 5.15^{*}$ \\
\hline & & $100 \mathrm{nM}$ & $10.13 \pm 10.81^{*}$ & $2.30 \pm 0.87 *$ & $8.18 \pm 5.24 *$ \\
\hline \multirow{3}{*}{\multicolumn{2}{|c|}{ TNF- $\alpha+$ DHMEQ }} & $1 \mathrm{nM}$ & $11.01 \pm 10.74 *$ & $2.38 \pm 1.23 * *$ & $5.67 \pm 3.25$ \\
\hline & & $10 \mathrm{nM}$ & $11.46 \pm 13.50^{*}$ & $2.32 \pm 1.14 * *$ & $3.89 \pm 3.36^{*}$ \\
\hline & & $100 \mathrm{nM}$ & $11.57 \pm 14.28^{*}$ & $2.01 \pm 0.77^{* *}$ & $3.41 \pm 2.42 *$ \\
\hline \multirow{3}{*}{\multicolumn{2}{|c|}{ TNF- $\alpha+$ FP + DHMEQ }} & $1 \mathrm{nM}$ & $9.00 \pm 8.50^{*}$ & $1.61 \pm 0.82 * * *$ & $3.99 \pm 3.30 *$ \\
\hline & & $10 \mathrm{nM}$ & $6.26 \pm 6.21 *$ & $1.35 \pm 0.95^{* * *}$ & $3.43 \pm 3.45^{*}$ \\
\hline & & $100 \mathrm{nM}$ & $4.56 \pm 5.26^{*}$ & $1.04 \pm 0.75^{* * *}$ & $2.57 \pm 2.57^{*}$ \\
\hline
\end{tabular}

Table 2. mRNA expressions of ICAM-1, VCAM-1 and RANTES, after TNF- $\alpha$ stimulation, either isolated or associated to different drugs and concentrations.Mean values and standard deviations, in folds compared to negative controls.P values when data were compared to positive controls. *: $\mathrm{P}<0.05$; ${ }^{* *}: \mathrm{P}<0.01$; ${ }^{* * *}: \mathrm{P}<0.005$.

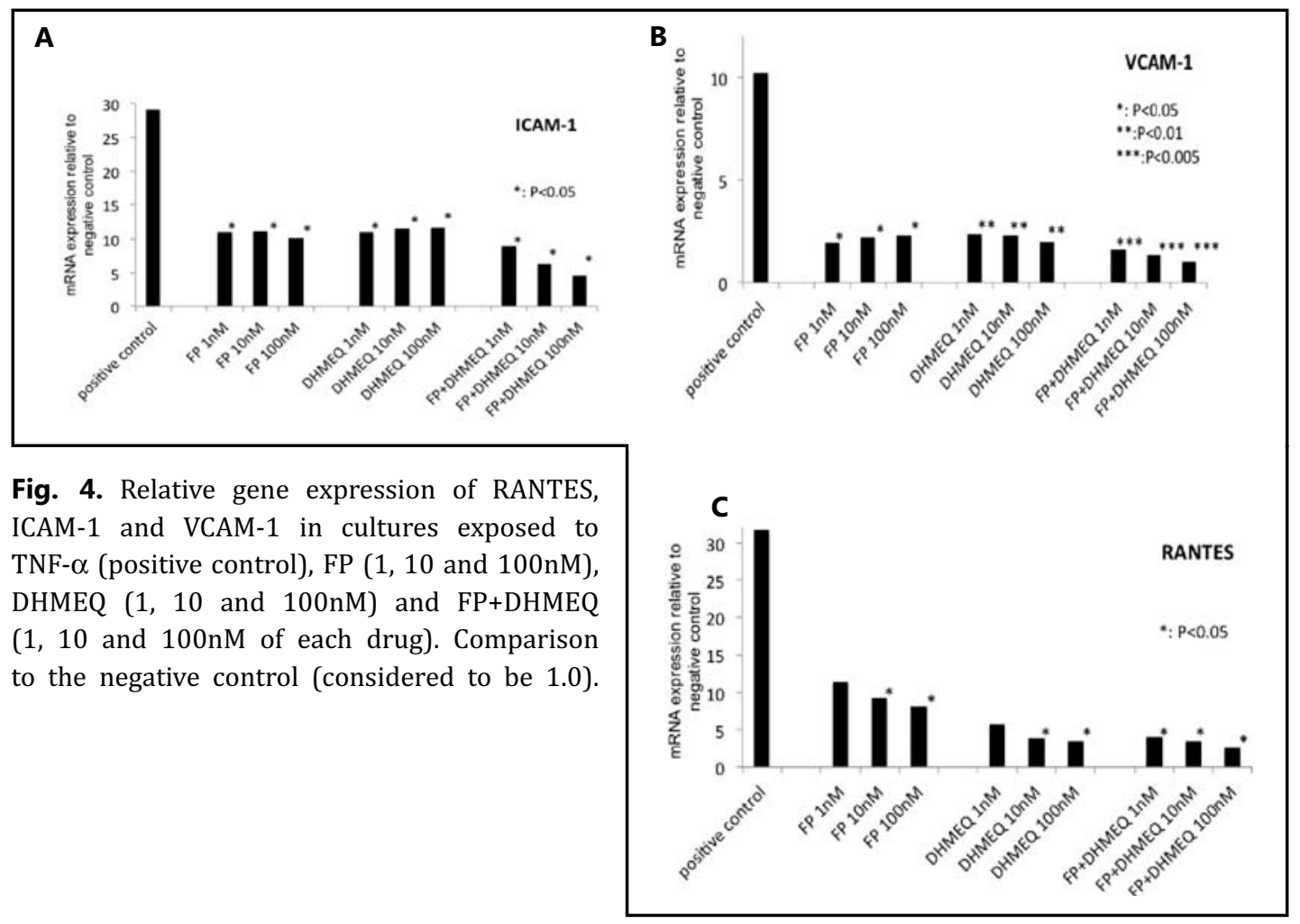

DHMEQ+FP concentrations for RANTES (DHMEQ+FP $1 \mathrm{nM}$ vs. TNF- $\alpha$ : $\mathrm{P}=0.0411$ ), and for the $10 \mathrm{nM}$ and $100 \mathrm{nM}$ DHMEQ+FP treatments for sVCAM-1 (DHMEQ+FP10nM vs. TNF- $\alpha$ : $\mathrm{P}=0.0117$ ) and for sICAM-1 (DHMEQ+FP10nM vs. TNF- $\alpha$ : $P=0.0205$ ). The association of both drugs led to a statistically different response from FP alone at the concentration of 10 and $100 \mathrm{nM}$ for both sICAM-1 ( $\mathrm{P}=0.0229)$ and RANTES $(\mathrm{P}=0.0409)$.

Inflammatory recruiters - $m R N A$ level (Table 2 and Figs. 4 a to $4 \mathrm{c}$ )

TNF- $\alpha 25 \mathrm{ng} / \mathrm{mL}$ significantly increased mRNA expression of ICAM-1 ( $\mathrm{P}=0.0004)$, VCAM$1(\mathrm{P}=0.0052)$ and RANTES $(\mathrm{P}=0.0312)$.

FP decreased genes expressionsin a dose-dependent pattern, which was significantly different from positive control at all FP concentrations for VCAM-1 (FP 1nM vs. TNF- $\alpha$ : 


\section{Cellular Physiology and Biochemistry}

Cell Physiol Biochem 2012;30:13-22

\begin{tabular}{l|l}
\hline DOI: $10.1159 / 000339042$ & $\begin{array}{l}\text { C 2012 S. Karger AG, Basel } \\
\text { www.karger.com/cpb }\end{array}$ \\
\hline Published online: June 05, 2012
\end{tabular}

Valera/Umezawa/Brassesco et al.: DHMEQ Study in Nasal Polyps Fibroblasts

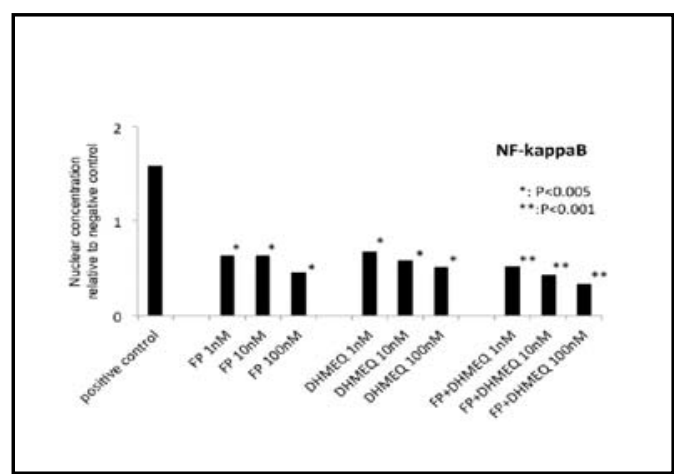

Fig. 5. Relative nuclear protein concentration of NF- $\kappa \mathrm{B}$ when cultures were exposed to TNF$\alpha$ (positive control), FP $(1,10$ and $100 \mathrm{nM})$, DHMEQ (1, 10 and 100nM) and FP+DHMEQ (1, 10 and $100 \mathrm{nM}$ of each drug). Comparison to the negative control (considered to be 1.0).

\begin{tabular}{lll}
\hline Stimulation & & NF-kappaB \\
\hline TNF- $\alpha$ & $1 \mathrm{nM}$ & $0.64 \pm 0.41^{*}$ \\
TNF- $\alpha+$ FP & $10 \mathrm{nM}$ & $0.64 \pm 0.42^{*}$ \\
& $100 \mathrm{nM}$ & $0.46 \pm 0.46^{*}$ \\
& $1 \mathrm{nM}$ & $0.68 \pm 0.43^{*}$ \\
TNF- $\alpha+$ DHMEQ & $10 \mathrm{nM}$ & $0.59 \pm 0.48^{*}$ \\
& $100 \mathrm{nM}$ & $0.52 \pm 0.34^{*}$ \\
& $1 \mathrm{nM}$ & $0.53 \pm 0.27^{* *}$ \\
TNF- $\alpha+$ FP + DHMEQ & $10 \mathrm{nM}$ & $0.44 \pm 0.29^{*}$ \\
& $100 \mathrm{nM}$ & $0.34 \pm 0.22^{* *}$ \\
\hline
\end{tabular}

Table 3. Nuclear translocation of NF-kappaB after TNF- $\alpha$ stimulation, either isolated or associated to different drugs and concentrations.Mean values and standard deviations, in folds compared to negative controls. $\mathrm{P}$ values when data were compared to positive controls. *: $\mathrm{P}<0.005$; **: $\mathrm{P}<0.001$.

$\mathrm{P}=0.0488$ ) and ICAM-1 (FP $1 \mathrm{nM}$ vs. TNF- $\alpha$ : $\mathrm{P}=0.0368$ ), and at the $10 \mathrm{nM}$ and $100 \mathrm{nM}$ FP treatments for RANTES (FP10nM vs. TNF- $\alpha$ : $P=0.0439$ ).

DHMEQ also decreased the inflammatory recruiters in a dose-dependent fashion, and the reduction was significantly different from positive control at all DHMEQ concentrations for VCAM-1 (DHMEQ 1nM vs. TNF- $\alpha$ : $P=0.010$ ) and ICAM-1 (DHMEQ $1 \mathrm{nM}$ vs. TNF- $\alpha$ : $\mathrm{P}=0.0291$ ), and at $10 \mathrm{nM}$ and 100nM DHMEQ treatments for RANTES (DHMEQ 10nM vs. TNF- $\alpha: P=0.0418$ ). Once more, this response was statistically similar from FP isolated.

The combination of both drugs (FP and DHMEQ) reducedthe inflammatory recruiters, which was significantly different from positive control at all DHMEQ+FP concentrations for VCAM-1 (DHMEQ+FP 1nM vs. TNF- $\alpha$ : $\mathrm{P}=0.0048$ ), ICAM-1 (DHMEQ+FP 1nM vs. TNF- $\alpha$ : $\mathrm{P}=0.0151$ ) and RANTES (DHMEQ+FP $1 \mathrm{nM}$ vs. TNF- $\alpha$ : $\mathrm{P}=0.0492$ ). The association of both drugs led to a statistically different response from FP isolated at the concentration of 10 and $100 \mathrm{nM}$ for both sVCAM-1 ( $\mathrm{P}=0.0313)$.

Nuclear translocation of $N F-\kappa B$ (Table 3 and Fig. 5)

The nuclearprotein concentration of NF- $\mathrm{KB}$ also increased when fibroblasts were exposed to positive stimulation ( $\mathrm{P}=0.0018)$; FP significantly decreased NF- $\kappa B$ translocation to nucleus, even at its lowest concentration (FP $1 \mathrm{nM}$ vs. TNF- $\alpha$ : $P=0.0022$ ). The same pattern was observed with DHMEQ, either isolated (DHMEQ $1 \mathrm{nM}$ vs. TNF- $\alpha$ : $P=0.0056$ ) or combined with FP (DHMEQ+FP $1 \mathrm{nM}$ vs. TNF- $\alpha$ : $\mathrm{P}=0.0006)$. Although the inhibition appeared to be increased when both drugs were combined compared to each drug in separate, this difference was not statistically significant for the nuclear translocation of NF- $\mathrm{KB}$.

\section{Discussion}

NP fibroblasts powerfully produce pro-inflammatory factors when induced by various stimuli. We observed that, when exposed to TNF- $\alpha$, NP fibroblasts amplify the RNA expression and protein secretion of VCAM-1, ICAM-1 and RANTES. Meyer et al. [23] also identified that TNF- $\alpha$ is a potent pro-inflammatory stimulus for NP cultures.

Silvestri et al. [6] observed, through flow citometry, that TNF- $\alpha$ for 24 hours $(0.5$ to 20 $\mathrm{ng} / \mathrm{mL}$ ) induced the expression of ICAM-1, but not VCAM-1, on NP fibroblasts. Yoshifuku et al. [24] reported that TNF- $\alpha(10 \mathrm{ng} / \mathrm{mL})$ for 24 hours was able to induce the secretion of RANTES and VCAM-1in nasal polyp fibroblast, evaluated by ELISA. Thus, there is agreement about the fact that, in general, TNF- $\alpha$ induces the expression of mRNA and the protein 


\section{Cellular Physiology and Biochemistry}

Cell Physiol Biochem 2012;30:13-22

\begin{tabular}{l|l}
\hline DOI: $10.1159 / 000339042$ & $\begin{array}{l}\text { C) 2012 S. Karger AG, Basel } \\
\text { www.karger.com/cpb }\end{array}$ \\
Published online: June 05, 2012 & w
\end{tabular}

www.karger.com/cpb

Valera/Umezawa/Brassesco et al.: DHMEQ Study in Nasal Polyps Fibroblasts

secretion of inflammatory factors. The data obtained in the present experiment agree with this pro-inflammatory profile of TNF- $\alpha$.

TNF- $\alpha$ also significantly increased the nuclear translocation of NF- $\kappa B$, suggesting this may be an important mechanism of induction of pro-inflammatory mediators. Ohori et al. [25] have also observed that TNF- $\alpha$ induced the expression of VCAM-1 in nasal fibroblasts, and this phenomenon was related to nuclear translocation of NF- $\kappa B$. These results confirm that TNF- $\alpha$ induces the activation of this TF, inducing the expression of other pro-inflammatory genes.

Fluticasone reduced the protein secretion and gene expression in fibroblasts superexposed to TNF- $\alpha$, in a dose-dependent pattern. Our results agree with those reported by Silvestri et al. [6], who observed that Fluticasone inhibited ICAM-1 secretion. Meyer et al. [23] evaluated different glucocorticoids (betamethasone and hydrocortisone), showing that they also inhibited the expression of RANTES on NP fibroblasts.

FP significantly inhibited the nuclear translocation of NF- $\mathrm{KB}$ in a very powerful way and even with very small concentrations of FP $(1 \mathrm{nM})$. This effect of fluticasone on NF- $\kappa B$ in nasal polyp fibroblasts had already been suggested by Silvestri et al. [6] and by our group [17], but no prior studies on nasal cell cultures have confirmed this effect to date.

The mechanism of action of glucocorticoids has not been fully elucidated. Its main antiinflammatory effect is believed to be inhibiting pro-inflammatory TFs. DHMEQ, in turn, is the first NF- $\mathrm{KB}$ inhibitor that acts specifically on its nuclear translocation, and not on its secondary compounds or on the phosphorylation of its inhibitor, IKB [26]. Thus, DHMEQ is believed to be highly specific for NF- $\kappa B$ inhibition, with much lower rate of side effects.

There is no literature report regarding the use of DHMEQ in NP cultures. Ohori et al. [25] evaluated the effect of a different NF- $\mathrm{KB}$ inhibitor, MG-132, on NP fibroblasts, and observed that it significantly reduced nuclear translocation of NF- $\kappa B$, as well as gene expression of VCAM-1. The authors concluded that VCAM- 1 expression is induced by NF- $\kappa B$, and that the use of a NF- $\kappa B$ inhibitor might be important strategy for treatinginflammatory nasal diseases.

We have evaluated the effect of DHMEQ on gene expression and on protein secretion of inflammatory recruiters produced by fibroblasts, as well as on nuclear translocation of NF$\kappa B$. Notably, as this was essentially a pre-clinical assay, our major objective was to determine whether DHMEQ displayed a satisfactory anti-inflammatory profile on a NP model, and not to define DHMEQ concentration for therapeutical use. We observed that DHMEQ significantly reduced the secretion of sVCAM-1, RANTES and sICAM-1 in a dose-dependent pattern. This pattern of reduction was alsoobserved at mRNA level, and also for nuclear translocation of NF- $\kappa B$ in NP fibroblasts, even at very low concentrations $(1 \mu \mathrm{M})$ of DHMEQ.

The reduction in nuclear translocation of NF- $\kappa B$ with DHMEQ was related to the decrease in VCAM-1, RANTES and ICAM-1. Yet, nuclear NF- $\kappa B$ reduction was much more pronounced during DHMEQ exposition than the production of pro-inflammatory molecules. Although we have not studied the influence of other TFs (like AP-1) on chemokines and adhesion molecules, this could be a reasonable explanation for this particular finding.

It is important to stress that the DHMEQ concentrations exploited in the present study were much lower than the doses used in previous experiments in other cultures [26, 27], as the concentration found to be toxic for NP fibroblasts cultures $(40 \mu \mathrm{M})$. Yet, these reduced doses of DHMEQ were chosen because our initial goal was to compare the effect of this drug to Fluticasone. Higher concentration of fluticasone in NP culture could lead to cell toxicity and reduction of cell viability [23].

Since the inflammatory inhibition of glucocorticoid is not limited to NF- $\kappa B$ pathway, we have also investigated whether the two drugs combined could potentiate their antiinflammatory effect. This information is especially important because association DHMEQ/ topical glucocorticoid could not only be synergic in potency, but also could decrease the concentration of each drug necessary to achieve anti-inflammatory pattern, and finally reduce the resistance to glucocorticoid.

In general, the present study showed that the association DHMEQ/ topical glucocorticoid reduced more pronouncedly the inflammatory recruiters, and lower drug concentrations of 


\section{Cellular Physiology and Biochemistry \\ Cell Physiol Biochem 2012;30:13-22 \\ \begin{tabular}{l|l}
\hline DOI: $10.1159 / 000339042$ & C 2012 S. Karger AG, Basel
\end{tabular} \\ Published online: June 05, 2012 \\ www.karger.com/cpb}

each drug were necessary to obtain the same anti-inflammatory results of monotherapy. In some concentrations, however, improvement was not significantly different.

Reports on the association of DHMEQ and other anti-inflammatory drugs are very scarce in the literature. Ueki et al. [27] studied the effect of DHMEQ and tacrolimus to inhibit the rejection of allogeneic heart transplant in rats, and concluded that the combined inhibition of NF- $\kappa B$ (by DHMEQ) and NFAT (by tacrolimus) strongly suppressed organ rejection, and thus improved survival rate and quality of life. Our results also point to an interesting rationale for the use of DHMEQ as an inhibitor of inflammatory mediators in NP, either separately or in combination with glucocorticoids.

This study provides the molecular bases for a new therapeutic strategy with a specific NFKB-targeting molecule to be evaluated in CRSwNP patients. Future studies are needed to determine the ideal doses and schedules of DHMEQ in CRSwNP patients, as well as its efficacy on controlled clinical trials for this disease.

\section{Acknowledgements}

Financial Support: FAPESP (process number: 07/50359-4). IRB approval: process number 4374/2007.

\section{References}

1 Pawankar R: Nasal polyposis: an update. Curr Opin Allergy Clin Immunol 2003;3:1-6.

2 Caversaccio M, Hartnell A, Calnan D, Jose P, Mackay IS, Uguccioni M, Baggiolini M, Williams TJ, Conroy DM: The role of chemokines in nasal polyps. Schweiz Med Wochenschr Supll 2000;125:92S-95S.

3 Couto LG, Fernandes AM, Brandão DF, Santi Neto D, Valera FC, Anselmo-Lima WT: Histological aspects of rhinosinusal polyps Braz J Otorhinolaryngol 2008;74:207-212.

4 Bernstein JM, Ballow M, Rich G, Allen C, Swanson M, Dmochowski J: Lymphocyte subpopulations and cytokines in nasal polyps: is there a local immune system in the nasal polyp? Otolaryngol Head Neck Surg 2004;103:526-535.

5 Van Zele T, Claevs S, Gevaert P, Van Maele G, Holtappels G, Van Cauwenberge P, Bachert C: Differentiation of chronic sinus diseases by measurement of inflammatory mediators. Allergy 2006;61:1280-1289.

6 Silvestri M, Sabatini F, Scarso L, Cordone A, Dasic G, Rossi GA: Fluticasone propionate downregulates nasal fibroblast functions involved in airway inflammation and remodeling. Int Arch Allergy Immunol 2002;128:51-58.

7 Adcock IM, Caramori G: Cross-talk between pro-inflammatory transcription factors and glucocorticoids. Immunol Cell Biol 2001;79:376-384.

8 Jahnsen FL, Haye R, Gran E, Brandtzaeg P, Johansen FE: Glucocorticosteroids inhibit mRNA expression for eotaxin, eotaxin-2, and monocyte-chemotactic protein-4 in human airway inflammation with eosinophilia. J Immunol1999;163:1545-1551.

9 Takeno S, Hirakawa K, Ueda T, Furukido K, Osada R, Yajin K: Nuclear factor-kappa B activation in the nasal polyp epithelium: relationship to local cytokine gene expression. Laryngoscope 2002;112:53-58.

10 Shin SH, Park JY, Jeon CH, Choi JK, Lee SH: Quantitative analysis of eotaxin and RANTES messenger RNA in nasal polyps: association of tissue and nasal eosinophils. Laryngoscope 2000;110:1353-1357.

11 Watanabe K, Shirasaki H, Kanaizumi E, Himi T: Effects of glucocorticoids on infiltrating cells and epithelial cells of nasal polyps. Ann OtolRhinolLaryngol 2004;113:465-473.

12 Fokkens W, Lund V, Mullol J: European position paper on rhinosinusitis and nasal polyps Rhinology 2007;Suppl20:1-136.

13 Pujols L, Alobid I, Benítez P, Martínez-Antón A, Roca-Ferrer J, Fokkens WJ, Mullol J, Picado C: Regulation of glucocorticoid receptor in nasal polyps by systemic and intranasal glucocorticoids. Allergy 2008;63:13771386.

14 Almawi WY, Melemedjian OK: Negative regulation of nuclear factor- $\kappa \mathrm{B}$ activation and function by glucocorticoids. J Mol Endocrinol 2002;28:69-78. 


\section{Cellular Physiology \\ Cell Physiol Biochem 2012;30:13-22 and Biochemistry

15 Valera FCP, Queiroz R, Scrideli C, Tone LG, Anselmo-Lima WT: Expression of transcription factors NF- $\kappa B$ and AP-1 in nasal polyposis. ClinExp Allergy 2008;38:579-585.

16 Valera FCP, Queiroz R, Scrideli C, Tone LG, Anselmo-Lima WT: Evaluating budesonide efficacy in nasal polyposis and predicting the resistance to treatment. Clin Exp Allergy 2009;39:81-88.

17 Valera FCP, Queiroz R, Scrideli C, Tone LG, Anselmo-Lima WT: NF- $\kappa B$ expression predicts clinical outcome for nasal polyposis. Rhinology 2010;48:408-414.

18 Umezawa K: Inhibition of tumor growth by NF-kB inhibitors. Cancer Sci 2006;97:990-995.

19 Shinoda K, Nakagawa K, Kosaka T, Tanaka N, Maeda T, Kono H, Mizuno R, Kikuchi E, Miyajima A, Umezawa K, Oya M: Regulation of human dendritic cells by a novel specific nuclear factor- $\kappa \mathrm{B}$ inhibitor, dehydroxymethylepoxyquinomicin. Hum Immun 2010;78:763-770.

20 Cardile V, Libra M, Caggia S, Frasca G, Umezawa K, Stivala F, Mazzarino MC, Bevelacqua Y, Coco M, Malaponte G: Dehydroxymethylepoxyquinomicin, a novel nuclear factor- $\kappa B$ inhibitor, prevents inflammatory injury induced by interferon- $\gamma$ and histamine in NCTC 2544 keratinocytes. Clin Exper Pharmacol Physiol 2010;37:679-683.

21 Saalbach A, Haustein UF, Anderegg U: A ligand of human Thy-1 is localized on polymorphonuclear leukocytes and monocytes and mediates the binding to activated Thy-1 positive microvascular endothelial cells and fibroblasts. J Invest Dermatol 2000;115:882-888.

22 Lee YJ, Shacter E: Oxidative stress inhibits apoptosis in human lymphoma cells. J BiolChem 199;274:1979219798.

23 Meyer JE, Berner I, Teran LM, Bartels J, Sticherling M, Schröder JM, Maune S: RANTES production by cytokine-stimulated nasal fibroblasts: its inhibition by glucocorticoids. Int Arch Allergy Immunol 1998;117:60-67.

24 Yoshifuku K, Matsune S, Ohori J, Sagara Y, Fukuiwa T, Kurono Y: IL-4 and TNF- $\alpha$ increased the secretion of eotaxin from cultured fibroblasts of nasal polyps with eosinophil infiltration. Rhinology 2007;45:235-241.

25 Ohori J, Ushikai M, Sun D, Nishimoto K, Sagara Y, Fukuiwa T, Matsune S, Kurono Y: TNF- $\alpha$ upregulates VCAM-1 and NF-kB in fibroblasts from nasal polyps. AurisNasus Larynx 2007;34:177-183.

26 Wakamatsu K, Nanki T, Miyasaka N, Umezawa K, Kubota T: Effect of a small molecule inhibitor of nuclear factor $\mathrm{\kappa B}$ nuclear translocation in a murine model of arthritis and cultured human synovial cells. Arthritis Res Ther 2005;7:1348-1359.

27 Ueki S, Yamashita K, Aoyagi T, Haga S, Suzuki T, Itoh T, Taniguchi M, Shimamura T, Furukawa H, Ozaki M, Umezawa K, Todo S: Control of allograft refection by applying a novel nuclear factor-kB inhibitor, dehydroxymethylepoxyquinomicin. Transplantation 2006;82:1720-1727. 